\title{
The emphysematous lung is abnormally sensitive to TRAIL-mediated apoptosis
}

\author{
Mathieu C Morissette, Julie Parent and Julie Milot ${ }^{*}$
}

\begin{abstract}
Background: Alveolar apoptosis is increased in the emphysematous lung. However, mechanisms involved are not fully understood. Recently, we demonstrated that levels of TRAIL receptor 1 and 2, levels of p53, and Bax/BCl- $\mathrm{X}_{\mathrm{L}}$ ratio were elevated in the lung of subjects with emphysema, despite smoking cessation. Thus, we postulate that due to chronic pulmonary oxidative stress, the emphysematous lung would be abnormally sensitive to TRAILmediated apoptosis.
\end{abstract}

Methodology: A549 cells were exposed to rTRAIL, cigarette smoke extract, and/or $\mathrm{H}_{2} \mathrm{O}_{2}$ prior to caspase-3 activity measurement and annexin $V$ staining assessment. In addition, freshly resected lung samples were obtained from non-emphysematous and emphysematous subjects and exposed ex vivo to rTRAIL for up to 18 hours. Lung samples were harvested and levels of active caspase- 3 and caspase- 8 were measured from tissue lysates.

Results: Both cigarette smoke extract and $\mathrm{H}_{2} \mathrm{O}_{2}$ were able to sensitize A549 cells to TRAlL-mediated apoptosis. Moreover, following exposure to rTRAIL, caspase-3 and -8 were activated in lung explants from emphysematous subjects while being decreased in lung explants from non-emphysematous subjects.

Significance of the study: Alveolar sensitivity to TRAlL-mediated apoptosis is strongly increased in the emphysematous lung due to the presence of oxidative stress. This might be a new mechanism leading to increased alveolar apoptosis and persistent alveolar destruction following smoking cessation.

Keywords: Apoptosis, COPD, oxidative stress, p53, TRAIL

\section{Introduction}

Emphysema, largely caused by cigarette smoking, is mainly characterized by a loss of alveolar integrity leading to poor gas exchange between the alveolar space and pulmonary capillaries [1]. Moreover, the emphysematous lung is an inflamed tissue in which activated neutrophils, alveolar macrophages and lymphocytes are found in large numbers [2]. In addition to proteases and inflammatory mediators, neutrophils and macrophages generate reactive oxygen species (ROS) [3,4]. This adds to oxidative stress aggression induced by primary cigarette smoke exposure and is responsible for the persistence of oxidative stress after smoking cessation [5].

High oxidative stress can damage cell lipids, proteins, and nucleic acids [6]. If too severe, such damage will force cells to activate their programmed cell death

\footnotetext{
* Correspondence: Julie.milot@criucpq.ulaval.ca

Centre de recherche de I'Institut universitaire de cardiologie et de pneumologie de Québec (CRIUCPQ), Québec, Canada
}

(apoptosis) [7]. Exposure to exogenous ROS acts on several apoptosis/survival-related signaling pathways such as MAPK, AKT, JAK/STAT, NF- $\kappa$ B and the DNA damage checkpoint involving p53 [7].

The transcription factor p53 is an important member of the cellular response to DNA damage. Depending on the severity of the DNA injuries, p53 will transcribe genes that will stop the cell cycle (i.e. $p 21,14-3-3 \sigma$ ) and allow DNA repair. However, p53 can also promote the transcription of pro-apoptotic genes (i.e. Bax, PUMA, NOXA, Fas, TRAIL-receptors 1 and 2) that will activate apoptosis and lead to cell death [8].

It is now well accepted that apoptosis is increased in the emphysematous lung [9-12], however, the cause is not fully understood. Our laboratory has previously demonstrated that a sub-lethal dose of hydrogen peroxide $\left(\mathrm{H}_{2} \mathrm{O}_{2}\right)$ activates p53 and up-regulates Bax and proapoptotic TRAIL-receptors (TRAIL-Rs) 1 and 2 in lung adenocarcinoma cells A549 [13]. These apoptotic factors

\section{Biomed Central}


were significantly increased in the lung of emphysematous subjects compared to normal smokers and nonsmokers, despite smoking cessation [13].

As the influence of elevated levels of p53, Bax, and TRAIL-Rs in the emphysematous lung on TRAILmediated apoptosis sensitivity is not known, we hypothesize that by up-regulating pro-apoptotic factors and TRAIL-Rs, sub-lethal oxidative stress may sensitize alveolar cells to the death ligand TRAIL.

\section{Methods}

\section{Cell culture and stimulations}

A549 cells (human lung adenocarcinoma derived cell line) were obtained from American Type Culture Collection (ATCC, Manassas, VA) and grown in DMEM with 10\% fetal bovine serum (FBS) (Cansera, PAA Laboratories, Etobicoke, ON, Canada). Cells were grown in 12-well culture plates to confluence at $37^{\circ} \mathrm{C}$ in the presence of $5 \% \mathrm{CO}_{2}$ and starved overnight in serum-free medium before stimulations. After medium was replaced with fresh serum-free DMEM, cells were exposed to $500 \mu \mathrm{M} \mathrm{H} \mathrm{H}_{2} \mathrm{O}_{2}$ or $5 \%$ cigarette smoke extract (CSE) (prepared according to Proulx et al. [14]) and/or recombinant TRAIL (rTRAIL) (Millipore, Billerica, Massachusetts) 30 and $100 \mathrm{ng} / \mathrm{ml}$ alone or with 5 $\mathrm{mM} \mathrm{N}$-acetyl-L-cystein (NAC) (antioxidant) (present $30 \mathrm{~min}$ before and during rTRAIL $/ \mathrm{H}_{2} \mathrm{O}_{2} / \mathrm{CSE}$ treatment) in serum-free medium. Cells were harvested $6 \mathrm{~h}$ after stimulation for caspase-3 activity assay and after $24 \mathrm{~h}$ for Annexin V staining. Each experiment was repeated three times.

\section{Human lung tissues}

Fresh human lung tissues were obtained from subjects undergoing lung resections for tumor with or without lung volume reduction. Lung specimens were located far from the tumor and verified by a pathologist to ensure that no tumor tissue was remaining. We obtained lung tissue specimens from 13 different subjects divided in two groups: subjects without airway obstruction or emphysema $(n=7)$ and subjects with airway obstruction and emphysema $(n=6)$. Presence of airway obstruction was based on $\mathrm{FEV}_{1}$ value and its reversibility following bronchodilator administration. All subjects were between 50 and 75 years old, with a smoking history greater than 15 packs-years. Subjects were matched for age, sex and smoking history. Presence of emphysema was confirmed by high resolution computed tomography scan (CT scan) analysis for all subjects with emphysema and by a pathologist for lung specimens. The "Institut universitaire de cardiologie et de pneumologie de Québec" (IUCPQ) Research Ethics Committee approved the study and all subjects provided written consent.

\section{Lung explants culture and stimulation}

Lung specimens were maintained in cold serum-free Dulbecco's modified Eagle medium (DMEM) (Invitrogen, Burlington, ON, Canada) following resection. Specimens were carefully cut (only parenchyma; no bronchi or pleural tissue) into approximately $9 \mathrm{~mm}^{3}$ explants, placed in collagen-coated 6-well culture plates (3/well) with serum-free DMEM only to prevent explants from drying and incubated $2 \mathrm{~h}$ to allow adherence of explants to collagen. Medium was then removed and new medium with or without $100 \mathrm{ng} / \mathrm{ml}$ of human rTRAIL was added to cover the explants (rTRAIL dose was determined after in vitro experiment). Explants were cultured for $0,6,12$ and $18 \mathrm{~h}$ before harvesting. For each condition, two explants were used for total protein extraction and one embedded in OCT for cryosectioning.

\section{Caspase- 3 activity assay}

Caspase-3 activity was measured in cultured lung explants and A459 cells with the Caspase-3 Fluorometric Assay Kit (BioVision, Mountain View, CA) according to manufacturer's specifications. For lung explants experiments, tissues were homogenized in the provided lysis buffer using glass beads ( $2 \mathrm{~mm}$ diameter) for $1 \mathrm{~h}$ before total protein concentration was measured (DC Protein Assay; Biorad, Hercules, CA). $40 \mu \mathrm{g}$ of total protein was used to measure caspase- 3 activity in lung explants lysates. For in vitro experiments, cells were lysed in the provided buffer before total protein concentration was measured. $50 \mu \mathrm{g}$ of total protein was used to measure caspase- 3 activity in cell lysate. Each measurement was done in duplicate.

\section{Flow cytometry analysis of annexin $\mathrm{V}$ binding}

Annexin $\mathrm{V}$ binding analysis was used to identify dead and dying A549 cells through both apoptosis and necrosis. A549 cells were trypsinysed (Trypsin $0.25 \%$, EDTA $2.2 \mathrm{mM}$ ) and incubated with Annexin V-FITC according to manufacturer's instructions (BD Biosciences, Mississauga, ON, Canada). At least 5000 cells were analyzed by flow cytometry on a Coulter EPICS XL-MCL flow cytometer (Beckman-Coulter; Mississauga, ON, Canada) with the EXPO 32 APC XL 4 Color program (BeckmanCoulter).

\section{Western Blot}

To determine activation of the extrinsic apoptotic pathway, caspase- 8 activation was assessed by Western blot in cultured lung explants. $40 \mu \mathrm{g}$ of protein was loaded in each lane and electrophoresed through $12 \%$ SDSpolyacrylamide gels followed by electrotransfer onto a nitrocellulose membrane. After staining with Ponceau Red to ensure that the same amount of protein was transferred onto the membrane, the membrane was 
incubated for $1 \mathrm{~h}$ in $5 \%$ fat-free dry milk powder in TBS and $0.05 \%$ Tween-20 (TBS-T) at room temperature (RT). The membrane was then incubated with the rabbit anti-human caspase-8 (1/1000) (BD Biosciences, Mississauga, $\mathrm{ON}$ ) in $5 \%$ fat-free dry milk powder in TBS-T overnight at $4^{\circ} \mathrm{C}$. Washes were done in TBS-T for 30 min. The membrane was then incubated with the horseradish peroxidase-conjugated goat anti-rabbit IgG (1/ 5000) (Cell Signaling Technology, Danvers, MA) diluted in $5 \%$ fat-free dry milk powder in TBS-T for $45 \mathrm{~min}$ at $\mathrm{RT}$. The membrane was washed for $30 \mathrm{~min}$ in TBS-T. Bands were revealed by chemiluminescent substrate addition according to manufacturer's insctructions (PerkinElmer, Woodbridge, Ont, Canada). Blots were then exposed to Bioflex MSI films (InterSciences, Markham, Ont, Canada) with intensifying screen. Bands were quantified by densitometry using Image J software (National Institutes of Health, USA).

\section{Histological analyses}

TUNEL and 4-hydroxy-2-nonenal (HNE) stainings, in addition to alveolar density index (ADI) determination, were performed on $8 \mu \mathrm{m}$ thick OCT embedded lung explants sections.

\section{TUNEL staining}

TUNEL staining was performed with DeadEnd Colorimetric TUNEL System (Promega Corp., Madison, WI) with modifications to manufacturer's specifications. Following rTdT treatment, sections were blocked with $2 \%$ BSA for $1 \mathrm{~h}$ at RT. Tissue autofluorescence was blocked with $0.1 \%$ Evan's blue (30 min, RT), and sections were then incubated with Streptavidin conjugated to Alexa 488 (0.01 mg/ml, $30 \mathrm{~min}$, TP; Life Technologies, Carlsbad, CA), counterstained with DAPI $(10 \mu \mathrm{M}, 15 \mathrm{~min}$, RT) and analysed by fluorescence microscopy.

\section{4-hydroxy-2-nonenal (HNE) staining}

Sections for HNE were fixed with acetone/methanol $(60 / 40)$ for $10 \mathrm{~min}$ at $-20^{\circ} \mathrm{C}$. Endogenous peroxydase was blocked with $0.3 \% \mathrm{H}_{2} \mathrm{O}_{2}$ for $30 \mathrm{~min}$ at RT. Staining steps were performed with the Vectastain Elite ABC kit (Vector Laboratories, Burlingame, CA) according to manufacturer's specifications. The primary antibody used was a rabbit anti-HNE (1/10 000) (Calbiochem EMD Chemicals, Gibbstown, NJ) $\mathrm{O} / \mathrm{N}$ at $4{ }^{\circ} \mathrm{C}$.

\section{Alveolar density index (ADI)}

For each lung specimen, three $40 \times$ pictures were taken from one $8 \mu \mathrm{m}$ thick OCT cut (hematoxylin \& eosin stained). A 20000 pixels grid (sides of 141.42 pixels) was superimposed over each picture (average of 20 squares/field) using Image J software. The number of alveoli walls crossing horizontal and the vertical lines was then counted and expressed as "intercepted alveolar wall/1000 linear pixels". A lower ADI indicates a more enlarged alveolus.

\section{Statistical Analysis}

Data from A549 cell stimulations were compared using one-way analysis of variance (ANOVA) followed by, if $p$ $<0.05$, a post-hoc Tukey-Kramer test. Data from subjects and cultured lung explants were compared using unpaired two-sided $\mathrm{T}$ test. Correlations were evaluated using Pearson's test and the significance using a onesample $\mathrm{T}$ test. A significant difference was assumed when $\mathrm{p}$ values were lower than 0.05 .

\section{Results}

In vitro study

\section{$\mathrm{H}_{2} \mathrm{O}_{2}$ and CSE sensitize A549 cells to TRAIL-mediated} apoptosis

A549 cells are resistant to TRAIL-mediated apoptosis up to $100 \mathrm{ng} / \mathrm{ml}$ as shown in Figure $1 \mathrm{~A}$ and $1 \mathrm{~B}$. Moreover, rTRAIL $30 \mathrm{ng} / \mathrm{ml}$ reduces baseline active caspase- 3 by $30 \%$ (Figure $1 \mathrm{~A}) \cdot \mathrm{H}_{2} \mathrm{O}_{2}(500 \mu \mathrm{M})$ or CSE (5\%) treatment alone mildly activated caspase-3, 154\% and 106\% of control respectively, and did not induce cell death in more than $10 \%$ of treated cells (Annexin V positive) (Figure 1B). However, exposure to both rTRAIL (100 ng/ml) $+\mathrm{H}_{2} \mathrm{O}_{2}$ or rTRAIL $(100 \mathrm{ng} / \mathrm{ml})+\mathrm{CSE}$ had synergistic effects on caspase- 3 activation, $570 \%$ and $420 \%$ of control respectively (Figure 1A), and on cell death induction, $+37 \%$ and $+25 \%$ annexin $\mathrm{V}^{+}$cells respectively (Figure 1B), when compared to untreated cells. Moreover, rTRAIL can be added up to $18 \mathrm{~h}$ following $\mathrm{H}_{2} \mathrm{O}_{2}$ treatment and still have synergistic effect with $\mathrm{H}_{2} \mathrm{O}_{2}$ on apoptosis induction (data not shown).

CSE-induced sensitization of A549 cells to TRAIL-mediated apoptosis is decreased by NAC

Exposure of A549 to $5 \mathrm{mM}$ of the ROS scavenger $\mathrm{N}$ acetyl-L-cystein (NAC) 30 minutes before and during exposure to $\mathrm{H}_{2} \mathrm{O}_{2}$ totally abrogated its TRAIL-sensitizing effect on A549 cells (Figure 2). However, NAC treatment only decreased the synergistic effects of CSE and rTRAIL on caspase-3 activation by $27 \%$ (Figure 2). Presence of NAC during the exposure (not only pretreatment) to $\mathrm{H}_{2} \mathrm{O}_{2} / \mathrm{CSE}$ and TRAIL is necessary to limit caspases-3 activation (data not shown).

\section{Ex vivo study \\ Clinical findings}

Characteristics of the subjects and resected lung tissues are presented in Table 1 and Table 2 respectively. The mean age and smoking history of the two groups were similar. Subjects were mostly ex-smokers (one active smoker in each group). Subjects with emphysema had moderate airway obstruction with a mean $\mathrm{FEV}_{1}$ at $50 \%$ of predicted value. Diffusion capacity of carbon monoxide $\left(\mathrm{DL}_{\mathrm{CO}}\right)$ was slightly reduced in subjects with emphysema with a mean value at $77 \%$ of predicted. Subjects without emphysema had normal lung function. The 

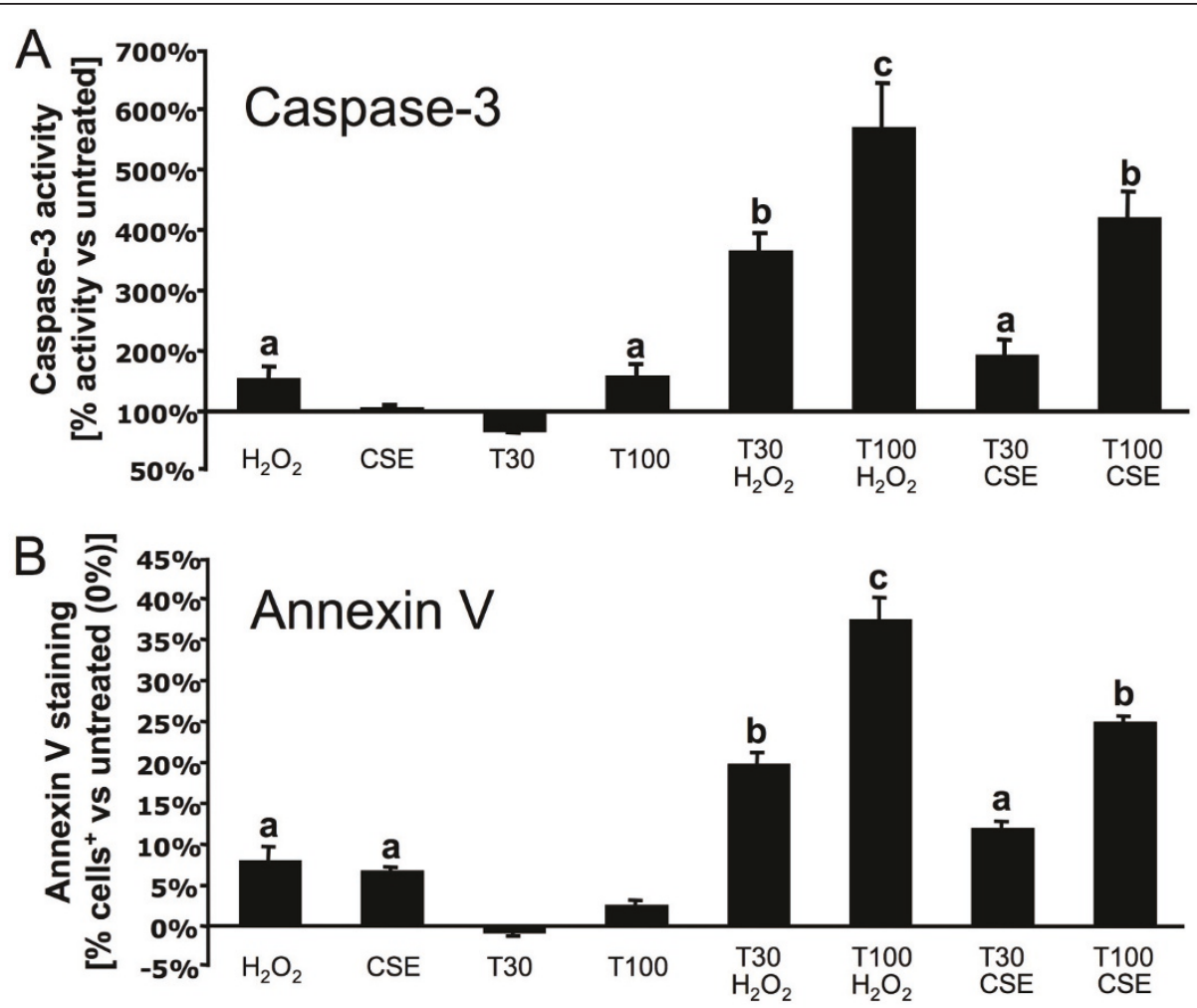

Figure $1 \mathrm{H}_{2} \mathrm{O}_{2}$ and CSE sensitize $\mathbf{A} 549$ cells to TRAIL-mediated apoptosis. A549 cells were exposed to $500 \mu \mathrm{M}$ hydrogen peroxide $\left(\mathrm{H}_{2} \mathrm{O}_{2}\right)$, $5 \%$ cigarette smoke extract (CSE) and/or 30-100 ng/ml of recombinant human TRAIL (T30-T100) for [A] $6 \mathrm{~h}$ (caspase-3 activity) or [B] $24 \mathrm{~h}$ (Annexin $V$ staining) in serum free media. Experiments were repeated three separate times. Results are expressed as means \pm SEM. Bars with different superscripts are significantly different $(p<0.05)$.

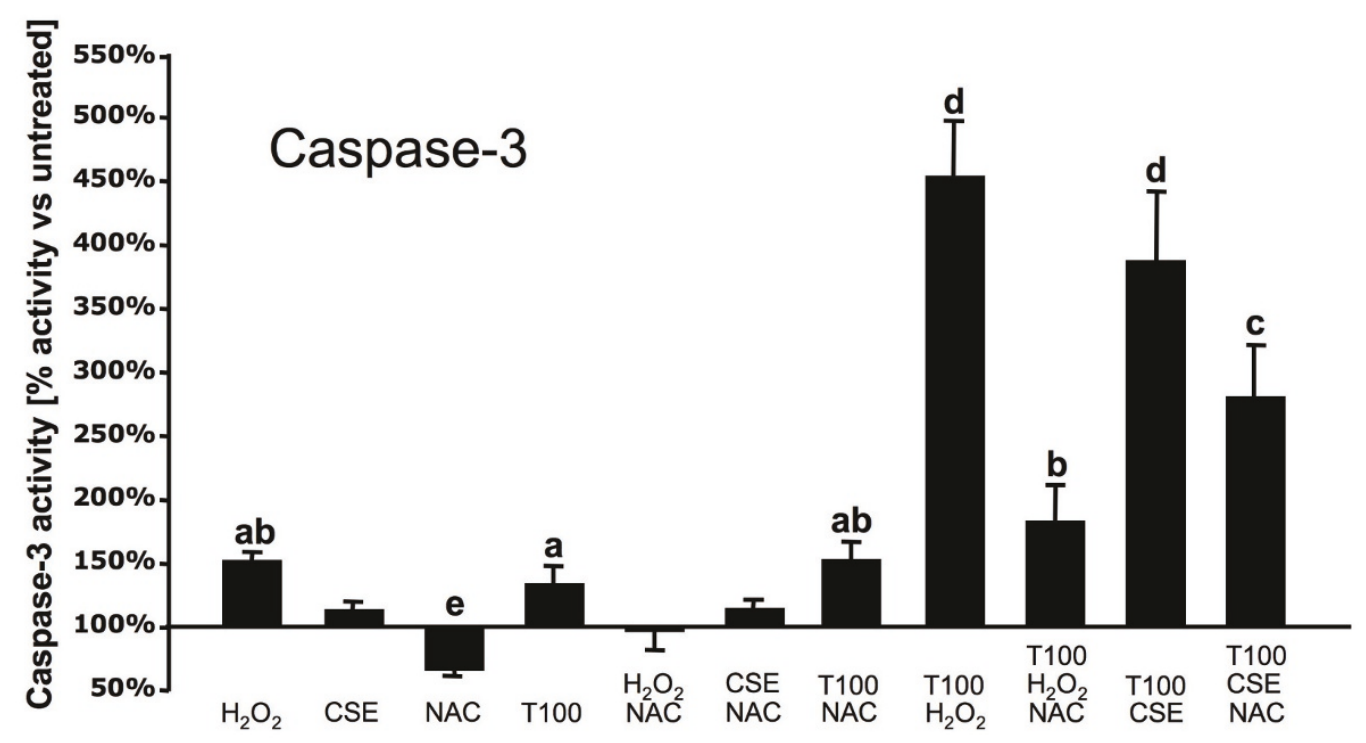

Figure 2 Oxidative stress is involved in A549 cells sensitization to TRAIL-mediated apoptosis induced by CSE. A549 cells were pretreated with $5 \mathrm{mM} \mathrm{NAC}$ and exposed to $5 \%$ cigarette smoke extract (CSE) or $500 \mathrm{mM} \mathrm{H}_{2} \mathrm{O}_{2}$ and/or $100 \mathrm{ng} / \mathrm{ml}$ of recombinant human TRAIL (T100) for 6 $\mathrm{h}$ in serum free media. Caspase-3 activity was then measured from the whole lysate. Experiments were repeated three separate times. Results are expressed as means \pm SEM. Bars with different superscripts are significantly different $(p<0.05)$. 
Table 1 Subjects' characteristics

\begin{tabular}{lcc}
\hline Variables & $\begin{array}{c}\text { Non-emphysematous } \\
\text { subjects }(\boldsymbol{n}=\mathbf{7})\end{array}$ & $\begin{array}{c}\text { Emphysematous } \\
\text { subjects }(\boldsymbol{n}=\mathbf{6})\end{array}$ \\
\hline Age, yr & $72+/-6$ & $66+/-8$ \\
Sex, female/male & $4 / 3$ & $3 / 3$ \\
FEV1, \% predicted & $97+/-17$ & $50+/-22^{*}$ \\
FEV1/FVC, \% & $71+/-6$ & $45+/-11^{*}$ \\
DLCO, \% predicted & $93+/-22$ & $77+/-36^{*}$ \\
Smoking history, & $52+/-27$ & $58+/-34$ \\
pack-year & & $1 / 5$ \\
Current/ex-smokers & $1 / 6$ & 6 \\
Presence of & - & \\
emphysema (CT & & \\
Scan) & & \\
\hline
\end{tabular}

* Significantly different from non-emphysematous subjects, $\mathrm{p}<0.05$

Results are presented as mean +/- standard deviation

presence of emphysema was confirmed by CT scan and by the pathologist for resected lung specimens. Alveolar density index (ADI) was significantly lower in lung specimens from emphysematous subjects than in nonemphysematous ([intercepted alveolar wall/1000 linear pixels] $12.4 \pm 2.2$ vs $18.7 \pm 3.3 ; \mathrm{p}<0.05$ ) (Table 2 ). HNE staining score (marker of oxidative stress) was significantly higher in lung specimens from emphysematous subjects than in non-emphysematous $(4.2 \pm 0.4 \mathrm{vs}$ $2.8 \pm 1.3 ; \mathrm{p}<0.05$ ) (Table 2).

\section{Ex vivo exposure to rTRAIL induces apoptosis in lung} explants from emphysematous subjects

Activity of caspase-3, a terminal caspase, and protein levels of active caspase- 8 , a caspase activated by death receptors such as TRAIL-R1/2, were measured to evaluate the effect of rTRAIL on apoptotic pathways activation (Figure 3A). Both caspases were elevated in lung explants with emphysema following $18 \mathrm{~h}$ of culture with rTRAIL compared to untreated lung tissues ([Area Under the Curve (AUC) rTRAIL treated/AUC untreated*100] Casp-3 +14.1\%; Casp-8 +20.7\%). However, caspases induction was not observed in non-

\section{Table 2 Lung tissues' characteristics}

\begin{tabular}{|c|c|c|}
\hline Variables & $\begin{array}{l}\text { Non- } \\
\text { emphysematous } \\
\text { tissues }(n=7)\end{array}$ & $\begin{array}{l}\text { Emphysematous } \\
\text { tissues }(n=6)\end{array}$ \\
\hline $\begin{array}{l}\text { Presence of emphysema } \\
\text { (determined by the } \\
\text { pathologist) }\end{array}$ & 0 & 6 \\
\hline $\begin{array}{l}\text { Alveolar density index } \\
\text { (intercepted alveolar wall/1000 } \\
\text { linear pixels) }\end{array}$ & $18.7+/-3.3$ & $12.4+/-2.2^{*}$ \\
\hline $\begin{array}{l}\text { 4-hydroxy-2-nonenal (HNE) } \\
\text { staining score }(0=\text { no staining; } \\
5=\text { max. staining) }\end{array}$ & $2.8+/-1.3$ & $4.2+/-0.4^{*}$ \\
\hline
\end{tabular}

emphysematous tissues ([AUC rTRAIL treated/AUC untreated"100] Casp-3 -13.8\%; Casp-8 -9.3\%) and was markedly decreased (Figure 3A).

In lung explants cultured for $18 \mathrm{~h}$ with rTRAIL, the number of cells undergoing apoptosis (TUNEL ${ }^{+}$cells) was increased in explants from emphysematous lung ([\% TUNEL $^{+}$TRAIL-treated $-\%$ TUNEL $^{+}$untreated] $+4.3 \pm$ $2.9 \%)$ and reduced in explants from non-emphysematous lung $(-2.9 \pm 2.4 \%)$ (Figure 3B). Moreover rTRAILmediated caspase- 3 activation correlated negatively with ADI $(\mathrm{r}=0.83, \mathrm{p}<0.001)$ (Figure $4 \mathrm{C})$, but not with HNE staining $(r=0.20, p=N S)$.

\section{Discussion}

We previously reported that p53 levels, TRAIL-R1/2 levels and $\mathrm{Bax} / \mathrm{Bcl}-\mathrm{x}_{\mathrm{L}}$ ratio were higher in the lung of emphysematous subjects as well as in A549 cells exposed to $\mathrm{H}_{2} \mathrm{O}_{2}$ and concluded that it might affect alveolar sensitivity to TRAIL-mediated apoptosis [13]. In line with those results, the present manuscript demonstrate that A549 cells exposed to $\mathrm{H}_{2} \mathrm{O}_{2}$ or CSE are susceptible to TRAIL-mediated apoptosis. This supports our main finding that ex vivo exposure of emphysematous lung explants to rTRAIL induced caspases activation and cellular death while rTRAIL had anti-apoptotic properties in non-emphysematous subjects. Moreover, caspase- 3 activation following rTRAIL treatment of lung explants correlated with alveolar density index (ADI). To the best of our knowledge, we are the first to report an increased sensitivity of the emphysematous lung to TRAIL-mediated cell death. This work identifies the increased sensitivity to TRAIL-mediated apoptosis as a mechanism for persisting alveolar destruction in the emphysematous lung after smoking cessation. Furthermore, using lung explant culture to test our hypothesis allowed us to study a functional characteristic of the human emphysematous lung.

Our most important finding was that rTRAIL treatment had differential effects on apoptosis induction depending on the presence or absence of emphysema in lung explants. In fact, despite significant smoking history, no apoptotic effect in response to TRAIL was observed in non-emphysematous subjects. Unexpectedly, in addition to rTRAIL having no apoptotic effect, it initiated an anti-apoptotic response. This is likely because TRAIL is able to activate transcription factor $\mathrm{NF}-\kappa \mathrm{B}$ and $\mathrm{AKT}$, as it has been demonstrated in vitro [15]. These signaling pathways are known to promote cell survival directly [16] or indirectly [17] through antiapoptotic factors such as cFLIP and members of the "inhibitor of apoptosis" (IAP) family (i.e. XIAP, cIAP1-2 and Survivin) that have the ability to prevent caspase- 8 and -3 activation. Thus, TRAIL might activate these anti-apoptotic pathways in non-emphysematous lung 

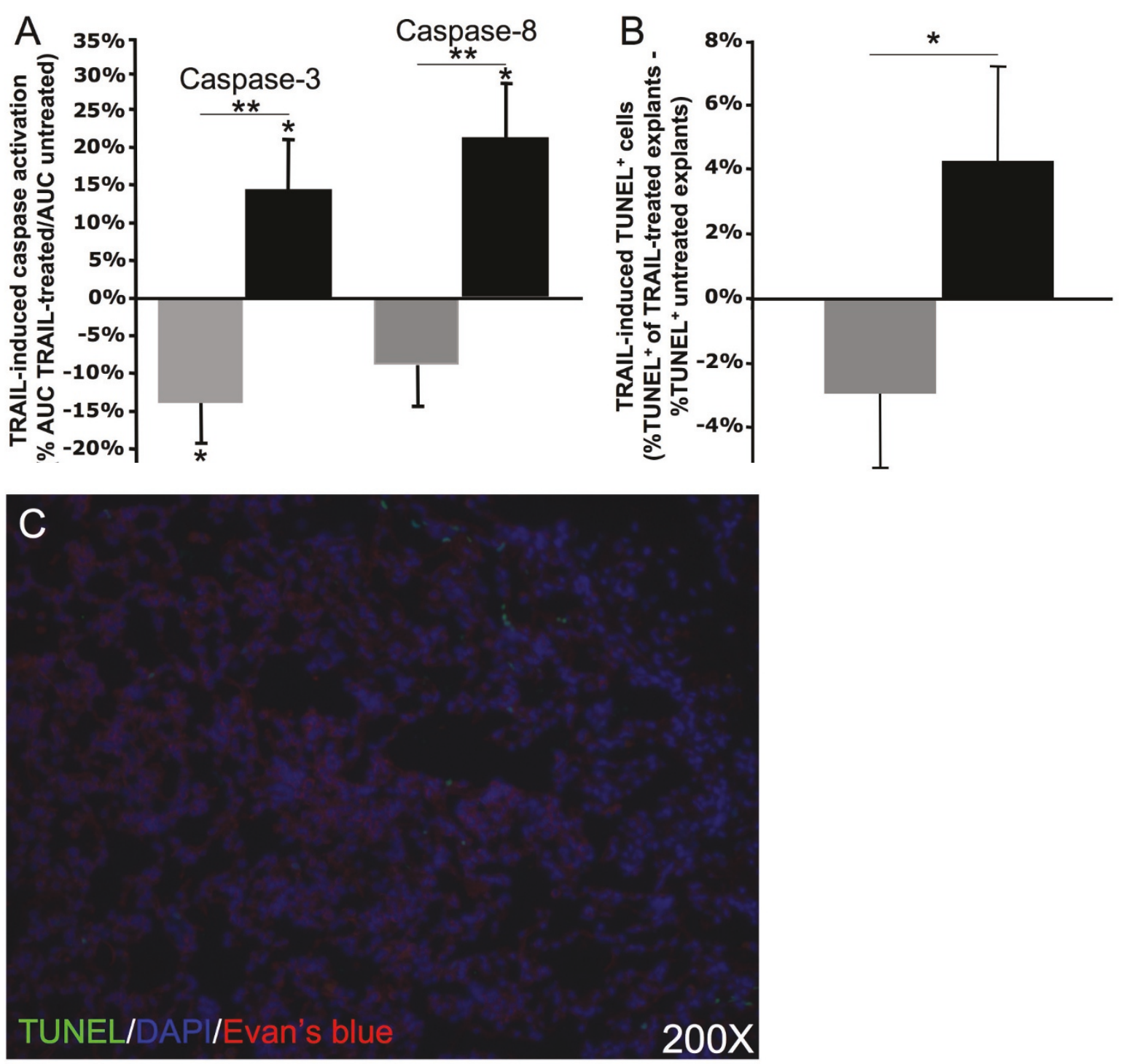

Figure 3 The emphysematous lung is abnormally sensitive to TRAIL-mediated apoptosis ex vivo. [A] Caspase-3 activity and active caspase-8 levels were assessed at 0, 6,12 and $18 \mathrm{~h}$ in untreated and rTRAll-treated lung explants from non-emphysematous (grey) and emphysematous subjects (black). For every subject, values obtained were used to determine the area under the curve (AUC) for untreated and rTRAIL-treated explants. The percentage of variation of the AUC was then determined for every subject ([AUC rTRAIL-treated/AUC untreated] *100). A positive percentage means that rTRAIL induced caspases activation. [B] TUNEL staining was performed on explants from every subject after $18 \mathrm{~h}$ of TRAIL treatment or culture control. Every TUNEL ${ }^{+}$(apoptotic) and DAPI ${ }^{+}$(nucleus) cells were counted and then the percentage of TUNEL $^{+}$was determined for every condition ([TUNEL $\left.\left.{ }^{+} / \mathrm{DAPI}^{+}\right]^{*} 100\right)$. For every subject, the effect of $18 \mathrm{~h}$ treatment of TRAIL on apoptosis induction was then determined as follow: \% TUNEL ${ }^{+}$TRAIL-treated - \% TUNEL ${ }^{+}$untreated. [C] Representative TUNEL staining of a lung explant used to measure TRAIL-induced apoptosis ex vivo. Results are expressed as means \pm SEM. ${ }^{*} p<0.05,{ }^{* *} p<0.01$.

explants, explaining the decreased caspase- 8 and -3 activity following TRAIL treatment. However, the lungs of subjects with emphysema are susceptible to proapoptotic activity of TRAIL at a large scale, despite smoking cessation. Our previous demonstration of high levels of TRAIL-R1/2, p53, and elevated Bax/Bcl- $\mathrm{x}_{\mathrm{L}}$ ratio in the emphysematous lung and in A549 cells exposed to $\mathrm{H}_{2} \mathrm{O}_{2}$ [13] might be responsible for the increased sensitivity to TRAIL-mediated apoptosis. In fact, we demonstrated that $\mathrm{H}_{2} \mathrm{O}_{2}$ alone sensitized A549 cells to TRAIL pro-apoptotic effects. Thus, oxidative stressinduced alterations observed in the emphysematous lung are likely to be responsible for shifting TRAIL signaling from anti- to pro-apoptotic pathways.

Importantly, this study documents a strong correlation between TRAIL-induced caspases- 3 activation and the 


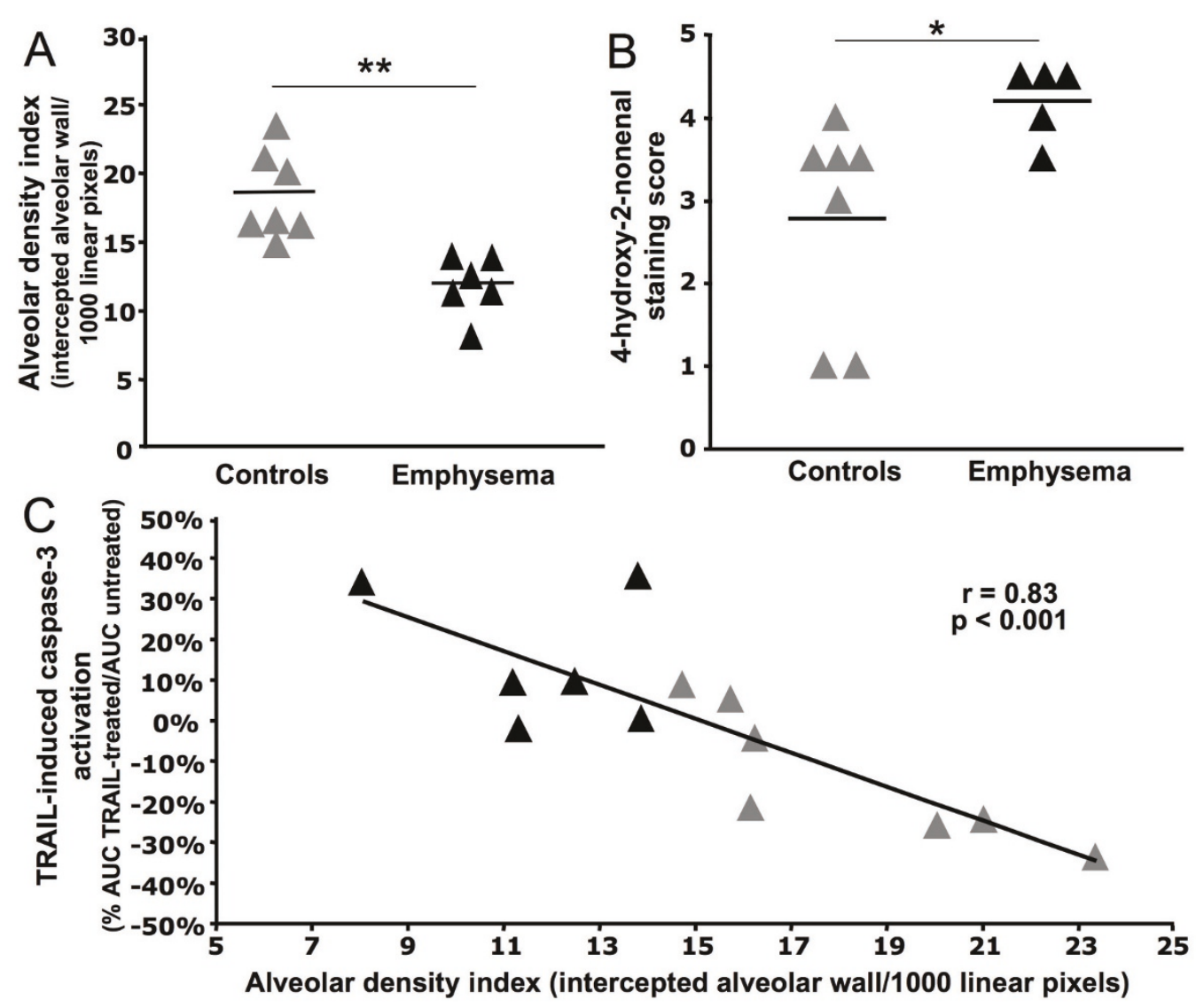

Figure 4 Sensitivity to TRAIL-mediated apoptosis correlates with lung destruction. [A] Alveolar density index was measured for every lung sample obtained. Bars represent the means. [B] 4-hydroxy-2-nonenal staining was performed for every subject (except one emphysematous subject) and blindly scored for staining intensity. Bars represent the means. [C] Correlation between TRAlL-induced caspase-3 activation in explants from every subjects and the alveolar density index values. Grey triangles represent non-emphysematous subjects and black triangles represent emphysematous subjects. ${ }^{*} p<0.05,{ }^{* *} p<0.01$.

alveolar density index (ADI) in lung explants. Alveolar destruction and the enlargement of the alveolar space are the main characteristics of emphysema. Thus, sensitivity to TRAIL is directly related to alveolar destruction, which strengthen its role in emphysema pathophysiology.

In accordance with increased oxidative markers in the emphysematous lung [5] and as oxidative stress increases TRAIL-R1/2 expression, p53 levels and Bax/ $\mathrm{Bcl}-\mathrm{xL}$ ratio (balance toward apoptosis) in A549 cells [13], we report that $\mathrm{H}_{2} \mathrm{O}_{2}$ and cigarette smoke sensitized A549 cells to TRAIL-mediated apoptosis in vitro. In fact, the cellular response to injury seems to be extremely important in allowing the TRAIL signaling pathway to induce apoptosis in various cell types (i.e. CRTMG, DU-145, PC-3, K562 and U397) [18,19]. Thus, cellular response of the emphysematous lung to injury induced by oxidative stress can lead to an increased alveolar sensitivity to TRAIL-mediated apoptosis.

We also show that preventing oxidative stress can prevent sensitization to TRAIL-mediated apoptosis. In vitro,
$\mathrm{H}_{2} \mathrm{O}_{2}$-mediated sensitization of A549 cells to TRAIL was abrogated by the antioxidant NAC. However, NAC only partly reduced CSE-mediated sensitization to TRAIL. This suggests that some of CSE effects are mediated by oxidative damages, yet the major effects being mediated by factors that could not be scavenged by NAC. Thus, as oxidative stress observed in emphysema is a strong inducer of TRAIL-sensitivity, non-oxidant molecules contained in cigarette smoke can also sensitize cells to TRAIL and might provide a rationale for cigarette smoke-enhanced progression of the disease in emphysematous smokers compared to those who stopped smoking [20].

A limitation of this study was the restricted use of A549 cells in the in vitro experiments. A549 cells are widely used in respiratory research [13,21-23] and are a good model to study resistance to TRAIL as they are known to be resistant to TRAIL-induced apoptosis $[24,25]$. Moreover, they can respond to oxidative stress $[13,26]$ and display functional apoptosis $[24,27]$. 
In this manuscript, and in addition to our previous findings [13], we identify oxidative stress-mediated alveolar cell sensitization to TRAIL as a potential causative mechanism in emphysema-related alveolar destruction. Moreover, this study strengthens the role of oxidative stress in the pathogenesis of emphysema and elucidates another of ROS injurious effects.

\section{Acknowledgements}

Authors would like to thank the "Banque de Tissus du RSR du FRSQ - site IUCPQ" for lung specimens, Dr. David Marsolais for his advises on the writing of the manuscript and James Kenneth Nikota for grammar revision.

\section{Authors' contributions}

MCM participated in the design of the study, carried out most experiments and drafted the manuscript. JP performed the tissue staining and helped to draft the manuscript. JM conceived the study and helped to draft the manuscript. All authors read and approved the final manuscript.

\section{Competing interests}

Mathieu C Morissette is the recipient of a Ph.D. studentship from the "Fonds de Recherche en Santé du Québec". Julie Parent declares that she has no competing interest. Julie Milot has received unrestricted research grant from "Groupe de Recherche en Santé Respiratoire/NYCOMED" and from "Réseau de Santé Respiratoire (RSR) du Fonds de Recherche en Santé du Québec".

Received: 24 March 2011 Accepted: 8 August 2011

Published: 8 August 2011

\section{References}

1. Mannino DM: COPD: epidemiology, prevalence, morbidity and mortality, and disease heterogeneity. Chest 2002, 121:121S-126S

2. Barnes PJ: Mediators of chronic obstructive pulmonary disease. Pharmacol Rev 2004, 56:515-548.

3. Dahlgren C, Karlsson A: Respiratory burst in human neutrophils. J Immunol Methods 1999, 232:3-14.

4. Gwinn MR, Vallyathan V: Respiratory burst: role in signal transduction in alveolar macrophages. J Toxicol Environ Health B Crit Rev 2006, 9:27-39.

5. Rahman I, van Schadewijk AA, Crowther AJ, Hiemstra PS, Stolk J, MacNee W, De Boer WI: 4-Hydroxy-2-nonenal, a specific lipid peroxidation product, is elevated in lungs of patients with chronic obstructive pulmonary disease. Am J Respir Crit Care Med 2002, 166:490-495.

6. Ryter SW, Kim HP, Hoetzel A, Park JW, Nakahira K, Wang X, Choi AM: Mechanisms of cell death in oxidative stress. Antioxid Redox Signal 2007, 9:49-89.

7. Martindale $\mathrm{J}$, Holbrook NJ: Cellular response to oxidative stress: signaling for suicide and survival. J Cell Physiol 2002, 192:1-15.

8. Hainaut P, Wiman KG: 25 Years of p53 Research. Springer 2005.

9. Segura-Valdez L, Pardo A, Gaxiola M, Uhal BD, Becerril C, Selman M: Upregulation of gelatinases $A$ and $B$, collagenases 1 and 2 , and increased parenchymal cell death in COPD. Chest 2000, 117:684-694

10. Yokohori N, Aoshiba K, Nagai A: Increased levels of cell death and proliferation in alveolar wall cells in patients with pulmonary emphysema. Chest 2004, 125:626-632.

11. Kasahara Y, Tuder RM, Cool CD, Lynch DA, Flores SC, Voelkel NF: Endothelial cell death and decreased expression of vascular endothelial growth factor and vascular endothelial growth factor receptor 2 in emphysema. Am J Respir Crit Care Med 2001, 163:737-744.

12. Imai K, Mercer BA, Schulman LL, Sonett JR, D'Armiento JM: Correlation of lung surface area to apoptosis and proliferation in human emphysema. Eur Respir J 2005, 25:250-258.

13. Morissette MC, Vachon-Beaudoin G, Parent J, Chakir J, Milot J: Increased p53 level, Bax/BCl-x(L) ratio, and TRAIL receptor expression in human emphysema. Am J Respir Crit Care Med 2008, 178:240-247.

14. Proulx LI, Pare G, Bissonnette EY: Alveolar macrophage cytotoxic activity is inhibited by 4-(methylnitrosamino)-1-(3-pyridyl)-1-butanone (NNK), a carcinogenic component of cigarette smoke. Cancer Immunol Immunother 2007, 56:831-838.
15. Falschlehner $\mathrm{C}$, Emmerich $\mathrm{CH}$, Gerlach $\mathrm{B}$, Walczak H: TRAlL signalling: decisions between life and death. Int I Biochem Cell Biol 2007, 39:1462-1475.

16. Kim D, Chung J: Akt: versatile mediator of cell survival and beyond. $J$ Biochem Mol Biol 2002, 35:106-115.

17. Graham B, Gibson SB: The two faces of NFkappaB in cell survival responses. Cell Cycle 2005, 4:1342-1345.

18. Kwon D, Choi K, Choi C, Benveniste EN: Hydrogen peroxide enhances TRAIL-induced cell death through up-regulation of DR5 in human astrocytic cells. Biochem Biophys Res Commun 2008, 372:870-874.

19. Perez-Cruz I, Carcamo JM, Golde DW: Caspase-8 dependent TRAlL-induced apoptosis in cancer cell lines is inhibited by vitamin $\mathrm{C}$ and catalase. Apoptosis 2007, 12:225-234.

20. Fletcher $\mathrm{C}$, Peto R: The natural history of chronic airflow obstruction. $\mathrm{Br}$ Med J 1977, 1:1645-1648.

21. Albino AP, Huang X, Jorgensen ED, Gietl D, Traganos F, Darzynkiewicz Z Induction of DNA double-strand breaks in A549 and normal human pulmonary epithelial cells by cigarette smoke is mediated by free radicals. Int J Oncol 2006, 28:1491-1505.

22. Kotelkin A, Prikhod'ko EA, Cohen II, Collins PL, Bukreyev A: Respiratory syncytial virus infection sensitizes cells to apoptosis mediated by tumor necrosis factor-related apoptosis-inducing ligand. J Virol 2003, 77:9156-9172.

23. Rahman I: Oxidative stress, transcription factors and chromatin remodelling in lung inflammation. Biochem Pharmacol 2002, 64:935-942.

24. Kim KB, Choi YH, Kim IK, Chung CW, Kim BJ, Park YM, Jung YK: Potentiation of Fas- and TRAIL-mediated apoptosis by IFN-gamma in A549 lung epithelial cells: enhancement of caspase-8 expression through IFNresponse element. Cytokine 2002, 20:283-288.

25. Frese S, Brunner T, Gugger M, Uduehi A, Schmid RA: Enhancement of Apo2L/TRAIL (tumor necrosis factor-related apoptosis-inducing ligand)induced apoptosis in non-small cell lung cancer cell lines by chemotherapeutic agents without correlation to the expression level of cellular protease caspase-8 inhibitory protein. $J$ Thorac Cardiovasc Surg 2002, 123:168-174

26. Dandrea T, Hellmold H, Jonsson C, Zhivotovsky B, Hofer T, Warngard L, Cotgreave I: The transcriptosomal response of human A549 lung cells to a hydrogen peroxide-generating system: relationship to DNA damage, cell cycle arrest, and caspase activation. Free Radic Biol Med 2004, 36:881-896.

27. Hsu YL, Cho CY, Kuo PL, Huang YT, Lin CC: Plumbagin (5-hydroxy-2methyl-1, 4-naphthoquinone) induces apoptosis and cell cycle arrest in A549 cells through p53 accumulation via c-Jun NH2-terminal kinasemediated phosphorylation at serine 15 in vitro and in vivo. J Pharmacol Exp Ther 2006, 318:484-494.

\section{doi:10.1186/1465-9921-12-105}

Cite this article as: Morissette et al:: The emphysematous lung is abnormally sensitive to TRAIL-mediated apoptosis. Respiratory Research 2011 12:105

\section{Submit your next manuscript to BioMed Central and take full advantage of:}

- Convenient online submission

- Thorough peer review

- No space constraints or color figure charges

- Immediate publication on acceptance

- Inclusion in PubMed, CAS, Scopus and Google Scholar

- Research which is freely available for redistribution

Submit your manuscript at www.biomedcentral.com/submit
C Biomed Central 